\title{
Girl power! Femvertising jako nowy trend w komunikacji marketingowej. Analiza zjawiska na podstawie wybranych kampanii
}

\section{Wstęp}

Dotychczas komunikacja marketingowa próbowała przywiązać konsumentki do marki tylko w jeden sposób: przedstawiając im niedościgniony ideał kobiecości, do którego mają dążyć. Nieistotne, czy była to perfekcyjna pani domu, czy piękna i wiecznie młoda modelka - kobiece niezadowolenie i ciągła pogoń za doskonałością napędzały sprzedaż. Naomi Wolf twierdzi, że kultura zamknęła kobiety w tzw. micie urody - konstrukcie społecznym, którego zawartość jest definiowana przez patriarchat ${ }^{1}$. Do akcji na przełomie lat 80 . i 90 . XX w. wkroczyła zatem trzecia fala feminizmu. Dostrzegała ona potrzebę dopuszczenia do głosu wszelkiego rodzaju mniejszości: etnicznych, religijnych, seksualnych. Przedstawicielki trzeciej fali skupiały się na różnicach między kobietami z rozmaitych ras, kultur, religii czy narodowości; kładły nacisk na ogromną liczbę koncepcji kobiecości i to, że ich tożsamość nie musi być jednorodna ${ }^{2}$. Obszar zainteresowań trzeciej fali stale się jednak poszerzał: od przemocy domowej, samookaleczania, zaburzeń odżywiania, przez operacje plastyczne, handel ludźmi, aż do seksualizacji mediów. Kobiety zaczęły domagać się edukacji seksualnej w szkołach, łatwiejszego dostępu do antykoncepcji i prawa do aborcji. Przedstawicielki tego nurtu wciąż widzą, jak wiele jest jeszcze do osiągnięcia

\footnotetext{
${ }^{1}$ N. Wolf, The Beauty Myth, New York 2002, s. 234.

2 Słownik społeczny, red. B. Szlachta, Kraków 2004, s. 310.
} 
w zakresie zrównania praw obu płci. Małymi krokami dokonują często znaczących zmian.

Podobnie jest w wypadku mediów i przekazów marketingowych. Wreszcie frustracja kobiet spowodowana niedostosowaniem komunikatów do ich oczekiwań została dostrzeżona przez marki. Okazało się, że można komunikować inaczej i to się sprawdza. Dove wypuściło kampanię „Prawdziwe piękno”, która okazała się ogromnym sukcesem. Może klientki, które czują się dobrze z sobą, chętniej dokonają zakupu? Badanie agencji SheKnows Media wykazało, że tak właśnie jest: 52\% ankietowanych kupiło produkt, ponieważ podobał im się sposób przedstawienia kobiet w jego reklamie, a $43 \%$ powiedziało, że dzięki temu dobrze czuły się, dokonując zakupu - wspierały markę. Co więcej, tylko $25 \%$ z 628 kobiet biorących udział w ankiecie zadeklarowało, że będą dalej używać produktu, jeśli kobieta w jego reklamie została według nich nierealistycznie zaprezentowana. Wyniki wykazują, że kobiety w znacznej mierze reagują na reklamy, które wspierają równość płci i - co ważniejsze - pamiętają prokobiece kampanie (92\% potrafiło wymienić przynajmniej jedną) ${ }^{3}$.

Jak każdy szybko rosnący trend, także zwiększone zainteresowanie konsumentek prokobiecymi markami zostało zauważone przez specjalistów do spraw komunikacji i szybko przez nich wykorzystane. Tak ukształtował się femvertising, który według Joanny Stopyry

jest częścią trendu empower women - wzmacniania kobiet. A ono zaczyna się od rozprawienia ze stereotypami, które przez całe dekady utrudniały kobietom ich walkę o swoje, ich dążenie do samorealizacji jako człowieka, nie tylko jako żony i mamy. Clue femvertisingu to dogłębne zrozumienie kobiet i przede wszystkim zdjęcie z nich odium stereotypowych ograniczeń. Ja określam ten nurt rehabilitacją marketingu 4 .

W niniejszym artykule analizie zostaną poddane cztery kampanie marek Dove i Always. Jako materiał badawczy wybrano funkcjonujące w ich ramach filmy reklamowe, billboardy, komunikację w mediach społecznościowych i strony internetowe. Zastosowana zostanie perspektywa feministyczna, która zakłada, że nie istnieje jedna słuszna definicja kobiecości - raczej jest to zbiór różnorodnych tożsamości etnicznych, religijnych czy kulturowych. Zbadano prezentowane obrazy kobiecości i tego, jakie zajmuje ona miejsce w świecie według nadawców komunikatów — zarówno na płaszczyźnie werbalnej, jak i wizualnej.

$\mathrm{Na}$ temat femvertisingu powstało dotychczas niewiele opracowań naukowych ${ }^{5}$. Te, które opublikowano do tej pory, skupiają się na samej definicji i historii powsta-

${ }^{3}$ http://www.adweek.com/news/technology/these-stats-prove-femvertising-works-160704 (dostęp: 2.01.2017).

${ }^{4} \mathrm{http}$ //www.proto.pl/wywiady/joanna-stopyra-czas-na-rehabilitacje-marketingu (dostęp: 3.01.2017).

${ }^{5}$ Mowa tu głównie o publikacjach: J. Bator, Wizerunek kobiety w reklamie telewizyjnej, Warszawa 1998; A. Korczyc, Konkurencja wyobraźni. Kobiece tabu w reklamie, „Kultura Popularna” 4, 2013, s. 68-78; A.J. Madera, Wizerunek kobiety w reklamie telewizyjnej, „Środkowoeuropejskie Studia Polityczne” 1, 2004, s. 181-199. 
nia pojęcia lub zdezaktualizowały się na tyle, że należałoby uzupełnić przedstawione w nich tezy. Niniejszy artykuł stanowi próbę wypełnienia istniejącego deficytu.

\section{Określenie metody badawczej}

Przedmiotem analizy jest femvertising jako trend w komunikacji marketingowej. Na potrzeby badania przyjęto, że komunikacja marketingowa obejmuje wszystkie aktywności komunikacyjne danej marki: outdoor, reklamę (zarówno prasową, jak i telewizyjną czy internetową), działania PR i social media oraz branding.

Podstawowym celem jest zweryfikowanie, jaki obraz świata i kobiecości wynika $\mathrm{z}$ femvertisingu. Komunikacja marketingowa za pomocą środków masowego przekazu ma bowiem ogromną siłę oddziaływania na odbiorców. Może zmienić wizerunek (w tym wypadku) kobiet i trwale zapisać nowe podejście do kobiecości w powszechnej świadomości. Badając femvertising jako nowy trend w komunikacji marketingowej, skupiono się także na tym, za pomocą jakich środków wyrazu i narzędzi komunikacyjnych konstruowany jest przekaz. Pozwoli to na lepsze zrozumienie natury femvertisingu i tego, co decyduje o jego skutecznym dotarciu do grupy docelowej.

W badaniu zostały przeanalizowane cztery komunikaty marketingowe marek Dove i Always z lat 2013-2016. Aby uniknąć zafałszowania wyników, wybrano po dwie kluczowe kampanie w ramach strategii komunikacyjnej wytypowanych firm, aby wykazać stopniową ewolucję przekazu oraz konsekwencję marek w komunikowaniu swoich wartości.

Punktem wyjścia dla opracowanej metodologii były wybrane elementy metody analizy semiotycznej przedstawione przez Umberta Eco w publikacji Pejzaż semiotyczny. Eco za fundamenty analizy semiotycznej uznaje w niej wskazanie i oznaczenie tzw. sematów - obszarów znaczeniowych, za pomocą których odbiorca komunikatu klasyfikuje i rozróżnia przedmioty postrzeżone i postrzegane ${ }^{6}$. Na podstawie definicji zaproponowanych przez Eco Anna Fedas opracowała następujące procedury:

- wyróżnienie i zidentyfikowanie tzw. sematów, czyli bloków, pól znaczeń, na podstawie których odbiorca zarówno rozpoznaje, jak i klasyfikuje przedmioty postrzegane lub postrzeżone;

- analizy na poziomie denotacji (opis bez interpretacji) oraz na poziomie konotacji (interpretacja + skojarzenia) ${ }^{7}$.

Prezentowaną metodologię w interesujący sposób rozwija Barbara Frątczak-Rudnicka w magazynie „Brief”. Sprawnie łączy ona podstawowe założenia analizy semiotycznej i przekłada je na grunt komunikacji marketingowej. Bierze pod uwagę zawar-

${ }^{6}$ U. Eco, Pejzaż semiotyczny, przeł. A. Weinsberg, Warszawa 1972, s. 203-211, 234-267.

${ }^{7}$ A. Fedas, Propozycja analizy przekazu wielokodowego billboardu i spotu reklamowego, „Rozprawy Komisji Językowej” 39, 2012, s. 122. 
tą w niej symbolikę $\mathrm{i}$ to, w jaki sposób przekazy są tworzone, nadawane i dekodowane w rozmaitych kontekstach. Na tej podstawie stwierdzono jej wysoką użyteczność dla celów prowadzonego badania. Przedstawiony model analizy semiotycznej komunikacji marketingowej pozwala analizować ją przez pryzmat określonych poziomów znaczeniowych ${ }^{8}$ :

a) poziomu zewnętrznej manifestacji - czyli wszystkie zewnętrzne, wizualne cechy przekazu;

b) poziomu dyskursywno-narracyjnego - obejmuje styl wypowiedzi, konotacje, motywy i symbolikę; na tym poziomie pojawia się logiczna argumentacja, a także elementy impresyjne (dowody bazujące na emocjach), stereotypy, powszechne przekonania leżące u podstaw argumentacji; definiuje się tutaj funkcje i wzajemne relacje narratora i adresata przekazu, rolę, w której stawia się markę względem odbiorcy, i wizję idealnego odbiorcy;

c) poziomu wartości - a zatem to, co jest dla marki ważne, jakie idee stanowią fundament jej strategii; przyjmuje się założenie, że w komunikacji podkreślane wartości będą stawiane w opozycji do wartości im przeciwnych, gdyż taka prezentacja jest cechą podstawową porządku kultury (piękno-brzydota, naturalność-sztuczność) i jednocześnie niesie z sobą duży potencjał narracyjny, dzięki niej można w niespodziewany sposób przełamywać obowiązujące stereotypy.

Wymienione poziomy mogą stanowić podstawę zarówno do systematycznego konstruowania, jak i dekonstrukcji przekazów marketingowych. Analizując w ten sposób komunikaty marketingowe, ukazuje się ich społeczne i kulturowe znaczenie, a także prawdopodobne ścieżki ich interpretacji. Przekaz będzie więc opierał się na manifestowaniu pewnych istotnych dla marki i jej odbiorcy wartości za pomocą odpowiednich środków wizualnych i werbalnych, interpretowanych przez adresata komunikatu na trzech wymienionych poziomach ${ }^{9}$. Analiza semiotyczna pozwoli na dokonanie ustrukturyzowanej interpretacji omawianych komunikatów.

\section{Analiza komunikacji wybranych marek}

\subsection{Dove}

\subsubsection{Kampania "Szkice prawdziwego piękna" („Real Beauty Sketches")}

Dove od 2004 r. prowadzi kampanię pod hasłem „Prawdziwe piękno”. Markę do działań zachęciło przeprowadzone przez nią badanie, które wykazało, że tylko 4\% kobiet na całym świecie uważa się za piękne. Anselmo Ramos, dyrektor kreatywny Oglivy \& Mather, zgodnie z linią komunikacyjną Dove, pragnął przekonać pozostałe $96 \%$

\footnotetext{
${ }^{8}$ B. Frątczak-Rudnicka, Analiza semiotyczna w komunikacji marketingowej, „Brief” 12, 2006, s. 46-47.

${ }^{9}$ Ibidem.
} 
kobiet, że również takie są. Stąd narodziny projektu „Szkice prawdziwego piękna”. Został on przygotowany przez agencję Ogilvy \& Mather Brazylia, dyrektora kreatywnego Anselmo Ramosa, copywritera Hugo Veiga, dyrektora kreatywnego Diego Machado i agenta produkcyjnego Veronicę Beach. Spot został nakręcony i wyreżyserowany przez Johna X. Careya za pośrednictwem Paranoid USA, z reżyserem zdjęć Edem Dawida, producentem zdjęć Stanem Sawickim i producentem wykonawczym Jamie’em Millerem. Kampania ruszyła na początku w czterech krajach: USA, Kanadzie, Brazylii i Australii, z czasem rozszerzając zasięg na 110 krajów i 25 języków. Kampania osiągnęla zaskakujące wyniki: jest to jedna z najczęściej oglądanych reklam w Internecie w ogóle - do tej pory odnotowano ponad 163 mln odsłon na całym świecie. Ponadto w 2013 r. spot wygrał Grand Prix Międzynarodowego Festiwalu Cannes Lions Kreatywności ${ }^{10}$.

$\mathrm{Na}$ początku widz obserwuje oświetloną miękkim, popołudniowym światłem przestronną, jasną halę. W tle gra delikatna, fortepianowa muzyka. Zatrudniony przez agencję rysownik siedzi na krześle i spokojnie opowiada o projekcie. Potem narracja przenosi się na uczestniczki. Są to kobiety w wieku ok. 20-40 lat, różnorodne etnicznie, zadbane, ale niekoniecznie wpisujące się w obowiązujący kanon piękna. Ich relacje brzmią jak zwierzenia, jakby opowiadały przyjaciółce przy kawie o tym, co im się przydarzyło. Często przyjmuje to formę głosu z offu, narracji dla obserwowanej akcji. Gdy widzi się twarze kobiet, są one kręcone kamerą „z ręki”, obraz lekko drży, stosowane są zbliżenia na różne części ciała bohaterek (oczy, dłonie). Tworzy to wrażenie oglądania dokumentu. Wszystko wydaje się subtelne i spokojne - nawet ubiór i makijaż uczestniczek projektu są delikatne, naturalne, pastelowe. Całość buduje atmosferę bezpieczeństwa. Właściwa akcja rozpoczyna się, gdy kobiety po kolei siadają $\mathrm{w}$ fotelu, a siedzący za kotarą rysownik każe im opisać ich wygląd. Bohaterki są raczej krytyczne, wskazują na zbyt wysokie czoło czy szpiczastą brodę. Rysownik w tym czasie, na podstawie ich opowieści, przygotowuje ich portret. Potem zaprasza na krzesło drugą, obcą poprzedniczce osobę, która wcześniej miała za zadanie się jej przyjrzeć i tym razem to ona opisuje twarz wcześniejszej uczestniczki. W efekcie powstają dwa szkice: pierwszy przedstawia, jak dana kobieta widzi siebie, a drugi - jak widzą ją inni. Nagle okazuje się, że to, co dla bohaterki było szpecącą wadą, nie było nawet zauważane przez ludzi. Następuje punkt kulminacyjny filmu: konfrontacja kobietom pokazywane są oba rysunki i ma miejsce wewnętrzna przemiana uczestniczek projektu. Po zapoznaniu się ze szkicami bohaterki dochodzą do wniosku, że powinny bardziej doceniać swoje naturalne piękno. Jedna z uczestniczek (mocno eksponowana, jedna ze starszych - siwiejące włosy, zmarszczki - bohaterek) podsumowuje, że ma ono wpływ na całe jej życie i funkcjonowanie w społeczeństwie. $\mathrm{Na}$ koniec widać przytulającą się parę, która ma za zadanie dodatkowo wzmocnić

${ }^{10} \mathrm{http}$ ://adwords360.pl/katalog-kampanii/youtube/dove-real-beauty-sketches-kulisy-kampaniiyoutube/ (dostęp: 5.01.2017). 
przekaz. Muzyka cichnie, pojawia się charakterystyczny dla marki Dove biały ekran z napisem granatowym fontem: „Jesteś piękniejsza, niż Ci się to wydaje”. Potem zdanie znika, zamiast niego widoczne jest logo Dove i pod nim hashtag \#Jestesmypiekne.

Przekaz kampanii opiera się na dychotomii „akceptacja-kompleksy”, próbując pokazać kobietom, że ich wady mogą istnieć jedynie w ich świadomości, a niekoniecznie muszą być zauważane przez otoczenie. Widać, że Dove skupia się na wyglądzie, udowadniając, że to, co indywidualne, wyjątkowe, czyni kobiety pięknymi. U podstaw przekazu leżą podstawowe wartości wyznawane przez markę: akceptacja, miłość, wsparcie i bezpieczeństwo. Buduje to podwaliny pod kolejne komunikaty wysyłane przez markę do odbiorców.

\subsubsection{Kampania "Jesteśmy piękne"}

Poprzednia kampania miała zasięg globalny. Interesujące będzie sprawdzenie, jak wyglądają elementy strategii komunikacyjnej Dove przeniesione na polski grunt. Idealnym przypadkiem do analizy jest kampania „Jesteśmy piękne” z 2016 r., przygotowana i zrealizowana przez firmy Ad Craft, BoxStudio, Mindshare Polska i Atelier PR. Kolejne badanie zrealizowane na zlecenie Dove wykazało, że mimo usilnych starań marki nadal tylko 2 na 10 Polek czują się piękne ${ }^{11}$. Dlatego też po raz pierwszy bohaterkami akcji zostały Polki, wpisujące się w wizerunek normalnych, przeciętnych kobiet, zróżnicowanych pod względem wieku i wyglądu.

Komunikacja opierała się na specjalnej, poświęconej akcji stronie internetowej oraz komunikacji w mediach społecznościowych. Strona www.jestesmypiekne.pl była zgodna z systemem identyfikacji wizualnej marki, wszystkie elementy nie wybiegały poza markową kolorystykę. Na stronie głównej pojawiało się logo marki, odnośniki do jej kont w serwisach Facebook i Instagram, linki do kolejnych sekcji i film stanowiący podstawę całej kampanii. Podstrona „O akcji” zawierała jedynie tekst opisujący akcję, jej cel i punkt wyjścia, a na dole strony - grupowe zdjęcie wszystkich uczestniczek. Sekcja „Raport o pięknie” łączyła film, obok niego button "Jesteśmy piękne” z licznikiem (po kliknięciu pojawia się informacja, ile razy w ciągu tego dnia kobiety powiedziały sobie, że są piękne) i poniżej najciekawsze wyniki badań przeprowadzonych przez Dove, opracowane w formie interesujących i estetycznych infografik. Dodatkowo marka udostępniała pod osobnym linkiem pełną wersję raportu do pobrania. Podstrona „Kobiety Dove” ma taki sam układ jak poprzednia: pod filmem i buttonem znajdowała się jednak sekcja typu slider ze zdjęciami pięciu par z filmu i ich wypowiedziami na temat tego, co je łączy, co jest w nich piękne i jaki jest ich ideał urody.

Bazą kampanii był film. Tym razem najpierw widać białe tło z granatowym napisem „Tylko 2 na 10 Polek uważa się za piękne. Zaprosiliśmy kobiety, by o tym po-

${ }^{11}$ http://www.jestesmypiekne.pl/o-akcji (dostęp: 5.01.2017). 
rozmawiać”. W tle gra subtelna muzyka fortepianowa, podobna do tej w „Szkicach prawdziwego piękna”. Pojawia się kobieta siedząca na kanapie w studiu urządzonym na wzór wygodnego, kobiecego salonu (wszystkie elementy utrzymane są w kolorach marki) - w tle stoi drewniany parawan i designerska lampa, ściany są białe, w centrum widać miękką granatową kanapę i leżący na niej, rzucony na oparcie, biały koc. Przed kobietą znajduje się stół z wazonem pełnym białych tulipanów. Biel ma się zapewne kojarzyć z delikatnością, czystością, kobiecością. Bohaterki to Polki w wieku od kilkunastu do ok. 50 lat. Mają subtelny makijaż i naturalnie układające się włosy, są ubrane w stroje spójne z SIW (czyli Systemem Identyfikacji Wizualnej) marki: białe i błękitne. Bohaterki wypowiadają się ciepło o innych znanych im kobietach, podkreślając to, co w nich najpiękniejsze. Następnie pojawia się biały ekran z napisem umieszczonym pod logo Dove „A Ty jesteś piękna?”. Kolejne ujęcia pokazują, że bohaterki wahają się, nie wiedzą, co odpowiedzieć. Znów biały ekran: „Pokazaliśmy kobietom, co mówiły o nich ich najbliższe”. Okazuje się, że uczestniczki biorą udział w akcji parami: matki z córkami, siostry czy przyjaciółki. Następne sceny pokazują, jak pary zasiadają wspólnie przed laptopem i słuchają, co mówiły o sobie nawzajem. Uczestniczki uśmiechają się do siebie, przytulają się i płaczą ze wzruszenia. Muzyka milknie, znowu widać biały ekran z napisem „Wszystkie jesteśmy piękne!”, w kolejnej scenie pojawia się logo Dove i wezwanie do działania „Powiedz to z nami”, pod spodem widać button znany ze strony www akcji i adres witryny.

Marka Dove hasłem „Wszystkie jesteśmy piękne!” sugeruje, że jej tożsamość i osobowość powinny być kojarzone z kobiecym punktem widzenia. Dove stawia się w roli przyjaciółki, mamy, siostry bohaterki, która kocha ją i zadba o nią jak nikt inny. Jednocześnie pokazuje jej, że cały świat nie zważa na jej drobne niedoskonałości i dostrzega jej piękno złożone $\mathrm{z}$ tych wszystkich indywidualności, które czynią ją tak niezwykłą. W swojej komunikacji marka odwołuje się do ciepła rodzinnego czy przyjacielskiego grona, w którym można liczyć na wsparcie i opiekę. Nawet scenografia, makijaż czy ubiór sugerują delikatność, łagodność, naturalność - czyli podstawowe korzyści komunikowane użytkowniczkom kosmetyków marki. Każdy omawiany element przekazu komunikacyjnego Dove składa się spójnie w jedną całość, budując leżący u podstaw marki przekaz, będący istotą wyznawanych przez nią wartości. Dove cały czas mówi: „Twoje ciało jest piękne i kochaj je!”, a idąc dalej tym tokiem myślenia: „Skoro je kochasz, to dbaj o nie jak najlepiej”, oczywiście kosmetykami Dove, gdyż to one zaopiekują się tobą jak najlepsza przyjaciółka.

Trwająca już ponad dekadę kampania Dove wzbudziła wiele kontrowersji. Zderzyły się tutaj poglądy osób autentycznie wzruszonych przekazem i tych, które uważały, że marka posługuje się truizmami. Może niekoniecznie piękno jest cechą przynależną każdej kobiecie? Poza tym dlaczego kobieta ponownie sprowadzana jest do kwestii urody? Czy koniecznie ktoś musi uznać ją za piękną (w taki czy inny sposób), by czuła się pewna siebie? Na te pytania marka nie odpowiedziała. Z punktu widzenia przedstawionej analizy można wywnioskować, że Dove wciąż waha się między zamy- 
kaniem kobiecości w micie urody, w którym dla kobiety bycie piękną stanowi wartość i posłuży się najróżniejszymi środkami, by je osiągnąć (czy podkreślić, skoro już się nim charakteryzuje), a powszechną akceptacją dla różnorodności i odmienności, charakterystyczną dla trzeciej fali feminizmu (mimo wszystko w reklamie Dove pojawiły się niemal wszystkie możliwe typy urody kobiet z każdej grupy wiekowej).

Studium przypadku tej marki pokazuje, jak trudno może być komunikacyjnie wyrwać się z obowiązujących społecznych schematów. Jednocześnie jednak udowadnia, że nawet pozostając w powszechnym dyskursie, można użyć jego środków wyrazu i stworzyć coś nowatorskiego. Dove zwraca swoimi reklamami uwagę na istotne kwestie i skłania odbiorców do zastanowienia. Choć przekaz leżący u podstaw tej komunikacji nie jest z punktu widzenia np. feminizmu przełomowy, to nawet drobne zmiany w myśleniu mogą doprowadzić do transformacji wizerunku kobiet w masowej świadomości.

\subsection{Always}

\subsubsection{Kampania \#Jakdziewczyna (\#LikeAGirl)}

Marka Always od zawsze starała się w jakiś sposób wspierać dorastające dziewczynki - czy to poprzez publikacje na temat menstruacji i dojrzewania, czy spotkania w szkołach, podczas których specjalistka opowiadała uczennicom o podstawach związanych ze zmianami zachodzącymi w ich ciałach.

W 2013 r. firma Procter \& Gamble (P\&G) zrozumiała jednak, że wartości marki nie są komunikowane odpowiednio wyraźnie i że strategia komunikacyjna zdecydowanie potrzebuje zmiany. Przeprowadzono badania, z których wynikało, że 56\% dziewcząt traci poczucie pewności siebie podczas dojrzewania, a jednocześnie właśnie wtedy następuje ich pierwszy kontakt z marką Always. Agencja Leo Burnett Chicago postanowiła w tej niszy znaleźć miejsce na działalność marki. W 2014 r. wystartowała zatem kampania \#LikeAGirl, do której filmy wyreżyserowała znana i nagradzana reżyserka dokumentów - Lauren Greenfield. Rezultaty przeszły wszelkie wyobrażenia - kampania wygrała Grand Prix w kategorii PR podczas festiwalu Cannes Lions w 2015 r., a według wyników badania przeprowadzonego pod koniec 2014 r. niemal 70\% kobiet i $60 \%$ mężczyzn stwierdziło, że „Ten film zmienił ich rozumienie określenia »jak dziewczyna «" 12 .

Na początku widz obserwuje sytuację zza kulis. Widać studio filmowe i ładną, nastoletnią blondynkę, która ustawia się przed kamerą. W tle słychać delikatną, fortepianową muzykę. Potem dziewczyna filmowana jest w planie półpełnym, widzimy przed nią rękę z klapsem filmowym. Na granatowym tle (w barwach marki) pojawia się napis „Co znaczy robić coś »jak dziewczyna«?”. Znów widać bohaterkę, od któ-

12 http://www.campaignlive.co.uk/article/1366870/case-study-always-likeagirl\#tvWai0tbIflyZqkl.99 (dostęp: 5.01.2017). 
rej kamera płynnie przechodzi za kulisy, do reżyserki siedzącej z ekipą i wydającej dziewczynie polecenia. Statystka ma robić pierwsze, co jej przyjdzie do głowy, gdy słyszy „biegaj jak dziewczyna”. Następujące po sobie ujęcia prezentują, w jaki sposób każdy z uczestników wykonuje zadania. Obserwujemy nastoletnie, niemal dorosłe dziewczyny, dorosłego mężczyznę i małego chłopca. Są zróżnicowani pod względem etnicznym i wyglądu. Bohaterowie mają pokazać, jak według nich rzuca, biega czy walczy dziewczyna. Wszyscy są nieporadni, słabi fizycznie i na granicy śmieszności w swoich próbach. Pojawia się napis stanowiący jednocześnie punkt zwrotny narracji: „Zapytaliśmy małe dziewczynki o to samo”. Potem następuje seria ujęć, w której te same polecenia wykonują małe dziewczynki, w wieku 5-13 lat. Dają z siebie wszystko, walczą, rzucają czy biegają ze wszystkich sił. Dziewczynka w tiulowej, czerwonej sukience (wyglądająca niepozornie i uroczo, jak mała królewna) na pytanie reżyserki z offu „Co to znaczy »biec jak dziewczyna«?” odpowiada „Biec najszybciej, jak potrafisz”. Na ekranie pojawia się pytanie „Kiedy robienie czegoś »jak dziewczyna« stało się obelgą?". Kamera pokazuje znanego już widzom chłopca. Pytany, czy obraził swoją siostrę, nie jest pewien, co odpowiedzieć, aż wreszcie stwierdza, że określenie „jak dziewczyna” obraża wszystkie dziewczyny. Znów widać napis: „Pewność siebie dziewczynek spada w wieku dojrzewania. Always chce to zmienić". Głos z offu pyta starszych uczestników eksperymentu, jak według nich określenie „jak dziewczyna” wpływa na dorastające dziewczynki. Jedna z nastolatek radzi młodszym koleżankom, by się nie przejmowały, że robią coś ,jak dziewczyna”. Przecież są dziewczynami i jeśli to, jak coś robią, jest skuteczne, to nie stanowi to problemu. Reżyser następnie pyta starszych bohaterów, jak teraz zademonstrowaliby dziewczęcy bieg. Odpowiedź czarnoskórej nastolatki stanowi narrację dla ujęcia kolejnej bohaterki z całej siły odbijającej piłkę kijem bejsbolowym. Widać wezwanie do działania: „Sprawmy, by \#jakdziewczyna znaczyło niesamowite rzeczy. Dołącz do nas, by wspierać dziewczęcą pewność siebie na always.com". Ostatnie dwa ujęcia zestawiają biegnącą szybko nastolatkę z narracją innej bohaterki, która stawia pytanie „Dlaczego »bieganie jak dziewczyna « nie znaczy wygranej w wyścigu?”. Muzyka milknie, na ekranie pojawia się logo Always i claim: „Rewrite the rules”.

Always używa podobnych środków wyrazu jak Dove w kampanii „Camera Shy”13 - zestawia poglądy dorosłych i dzieci. Bezpretensjonalność dziewczynek stoi tu w opozycji do stereotypowego myślenia starszych bohaterów. W przeciwieństwie do

13 Kampania „Camera Shy” dotyczy nieopisanej w niniejszym artykule kampanii „Nieśmiała kamera Dove". Była to kampania stworzona w 2013 r. przez brytyjski oddział agencji Oglivy \& Mather, emitowana zarówno w mediach tradycyjnych (także w Polsce), jak i w Internecie. Dove również tym razem postawiło na spójną linię komunikacyjną: na Twitterze i Facebooku prowokowało do dyskusji na temat tego, jak wzmocnić swoją pewność siebie, a na specjalnie poświęconej kampanii podstronie zamieszczało porady odnośnie do tego, jak czuć się dobrze z sobą i nie bać się już aparatu fotograficznego. Osią komunikacji jak zwykle do tej pory był film, w którym pokazano, jak bohaterki uciekają przed osobą próbującą zrobić im zdjęcie, zasłaniają rękoma twarz lub obiektyw. Następnie zestawione jest to 
Dove, tutaj optyka skupia się na dzieciach i ich problemach. Always pochyla się nad dziewczynami stojącymi u progu przemian, kiedy ich pewność siebie jest zagrożona. Więcej tu dydaktyzmu, naprowadzania bohaterów na właściwą ścieżkę kilkoma trafnymi pytaniami. Film skupia się na wskazaniu widzom konkretnego problemu i jednocześnie zachęca, by małymi kroczkami dokonywać zmiany. Wzywa, by tworzyć w Internecie wielki krąg inspiracji dla młodych dziewcząt - by inne młodsze i starsze kobiety pokazały im, że robić ,jak dziewczyna" można mnóstwo niesamowitych rzeczy. W oczy rzuca się aktywność fizyczna jako jeden z motywów przewodnich produkcji i wartość, która ma dla marki szczególne znaczenie oraz do której podjęcia pewność siebie, czyli kolejna istotna dla Always kwestia, jest niezbędna.

\subsubsection{Kampania "Girl Emojis"}

Rok 2016 to rok emoji, czyli emotikonów wysyłanych często zamiast wiadomości tekstowych. Always zauważyło jednak, że mało emoji trafia w gust młodych dziewczyn i postanowiło zareagować. W związku z tym powstał film „Girl Emojis”, w którym dziewczyny w wieku 10-15 lat, siedzące na szkolnej sali gimnastycznej, narzekają do kamery, że emoji nie do końca odpowiadają temu, co chciałyby wyrazić. Są tylko różowe, nie ma kobiecych wersji sportsmenek ani innych zawodów, jedyne żeńskie emoji wyrażają nieporadność lub co najwyżej dbanie o wygląd. Punkt zwrotny stanowi pojawiające się na ekranie pytanie: „Podczas dojrzewania pewność siebie dziewczyn drastycznie spada. Więc o czym to świadczy, jeśli nawet emoji ograniczają je do stereotypów?". Jedna z bohaterek stwierdza, że chciałaby, żeby dziewczyny dorastały, wiedząc, że mogą być kimkolwiek zechcą. Znów pojawia się napis: „Always chce, by każda dziewczyna była pewna siebie. Uczyńmy zatem emoji tak niepowstrzymanymi jak dziewczyny, które przedstawiają". W serii kolejnych ujęć każda z bohaterek filmu pokazuje swoje pomysły na nowe, dziewczęce emoji. Jest zapaśniczka, łuczniczka, rowerzystka, perkusistka, policjantka, prawniczka, detektyw czy piosenkarka szalejąca na scenie. Spot kończy pytanie Always i zachęta do dyskusji „A jakie dziewczęce emoji ty byś chciała zobaczyć? Opowiedz nam pod hashtagiem \#likeagirl". Tradycyjnie wszystko wieńczy logo marki i claim.

Claim Always zdaje się mówić wszystko. „Napisz zasady od nowa!” - krzyczą. Faktycznie można uznać, że próbują to zrobić. W przeciwieństwie do Dove nie skupiają się na wyglądzie zewnętrznym dziewczyn, tylko pytają je, jakie mają ambicje, do czego dążą i starają się im pomóc to osiągnąć. Podważają zastaną sytuację i robiąc badania wśród dorastających dziewcząt, wyciągają z nich konstruktywne wnioski. Zauważają istniejące problemy i chcą im zaradzić, jednocześnie zmieniając coś w świecie. Stawiają się w roli matki, starszej siostry czy wręcz mentorki, która jest inspiracją

z bezpretensjonalnym zachowaniem małych dziewczynek. Zob. https://www.unilever.pl/news/aktualnosci/2013/niesmiala-kamera-dove.html (dostęp: 5.01.2017). 
dla młodych dziewcząt, a przy tym spogląda zatroskana na obecną sytuację i martwi się o to, z jakimi stereotypami muszą się one zmierzyć, będąc kobietami. Stawia na to, by raczej być, osiągać rzeczy wielkie, niż wyglądać. W duchu trzeciej fali feminizmu wytyka pozornie drobne zabiegi komunikacyjne, które mają wielką moc zamykania dziewczyn w określonych ramach i podtrzymywania szkodliwego dla nich dyskursu (którego manifestacją są np. emoji). Nie trywializuje tych problemów, za pomocą twardych danych nadając im odpowiednią wagę. Jednocześnie mówi do matek, by te wiedziały, jak pomóc swojej dorastającej córce zyskać więcej pewności siebie, wychodząc z założenia, że więź matki z córką jest wyjątkowa, wszak to ona wprowadza młodą dziewczynę w dorosłość i uczy, jak być kobietą. Always wspiera dziewczęta, chce dać im moc, by mogły osiągnąć wszystko, co sobie wymarzą. Wartości marki, które wychodzą na pierwszy plan, czyli: sport, motywacja, aktywność, pewność siebie i zero ograniczeń, tworzą spójną całość z przeżyciami potencjalnej klientki, do której kierowany jest przekaz. W końcu to właśnie tak każda kobieta chciałaby się czuć podczas menstruacji. Świadczy to o głębokim przemyśleniu obranej strategii, a połączenie tego $\mathrm{z}$ treściami feministycznymi dowodzi, jak wielką moc może mieć femvertsing i że faktycznie, choć jego celem jest również zysk firmy, można dzięki niemu stopniowo osiągać społeczną przemianę.

\section{Wnioski i podsumowanie}

Niniejsza analiza miała na celu zweryfikowanie, jaki obraz świata i kobiecości jest przedstawiany w komunikacji marketingowej nurtu femvertising. W badaniu wyszczególniano użyte w kampaniach środki wyrazu i sprawdzano, jaki w efekcie wizerunek kobiet jest za ich pomocą budowany, a także w jaki sposób pozostaje on w spójności z wizją, misją i deklarowanymi wartościami danej marki. Przeanalizowano cztery kampanie w ramach strategii komunikacyjnych marek Dove i Always. Choć działają one, wykorzystując ten sam trend, osiągają zupełnie inny rezultat. Na podstawie badania można podzielić przekazy w ramach femvertisingu na dwa zasadnicze podtypy, odpowiadające $\mathrm{w}$ uproszczeniu przedstawianej przez marki wizji świata i kobiecości jako takiej.

\subsection{Kocham cię taką, jaką jesteś}

Analiza wykazała, że u podstaw części komunikatów femvertisingu leży m.in. bezwarunkowa akceptacja różnorodności. Czuć tu wyraźną inspirację trzecią falą feminizmu, która dostrzegła, że kobiety jako grupa nie stanowią jednolitej masy, ale raczej chór wielu głosów, z którego każdego należy wysłuchać. Marka Dove skupiła się na (dość drażliwej w wypadku feminizmu) kwestii ciała. W swojej komunikacji pokazywała kobiety w różnym wieku, o odmiennych kolorach skóry i typach sylwet- 
ki. Wyszła poza ramy standardowego ideału piękna (podobnie marka Adrian, która na swoich billboardach pokazała kobiety niepełnosprawne, starsze czy po mastektomii). W tego typu przekazach nie poznajemy wykonywanych przez ich bohaterki zawodów, jednak widać, że są to przeciętne kobiety, które łączą role zawodowe z obowiązkami domowymi i życiem rodzinnym. Mają męża, dzieci, hobby (np. czytanie książek), uczą się, pracują. Bawią się, śmieją, czasem bywają zmęczone - chciałoby się rzec: „jak każdy”. Obserwujemy bohaterki bez makijażu, śpiące w łóżku, czasem lekko rozczochrane, w swobodnych strojach, w lekkim nieładzie, lecz mimo wszystko wciąż zadbane. Niezwykle ważne są nawiązywane przez kobietę więzi, zwłaszcza z innymi przedstawicielkami „płci pięknej”. Prezentowane są pełne miłości relacje matek z córkami, sióstr czy przyjaciółek. Razem tworzą niemal pierwotny krąg wzajemnego wsparcia i akceptacji. Do tej pory marki starały się celowo pogłębiać kobiece kompleksy odnośnie do wyglądu. Dove postanowiło odwrócić sytuację i pokazać kobietom, że są piękne niezależnie od niedoskonałości, albowiem to właśnie wszystkie charakterystyczne drobnostki czynią ludzi niezwykłymi indywidualnościami. Aby pomóc bohaterkom pokonać kompleksy, marki wykorzystują zewnętrzną, bezwarunkowo akceptującą je siłę. Może ona wynikać z bliskich relacji kobiet: matki czy przyjaciółki, które wskażą im, że mają w sobie wiele pięknych detali; może być to obca osoba, która po prostu nie dostrzeże rzeczy, które uczestniczka filmu uważa za swoje wady, lub często to wręcz sama marka stawia się w roli kogoś, kto kocha i widzi bijący od kobiety blask - Adrian „Kocha wszystkie kobiety”, Dove z kolei stwierdza, że „Wszystkie jesteśmy piękne!”. Można uznać, że tego typu linia komunikacji doskonale łączy się z przedstawianymi konsumentce korzyściami - że akurat w produktach danej marki każda kobieta znajdzie coś dla siebie i będzie czuła, iż z jej pomocą odpowiednio o siebie zadba.

\subsection{Kobieta potrafi!}

W analizie reklam Always dostrzeżono, że nie każdy przekaz skupia się wyłącznie na pokonywaniu przez kobiety kompleksów związanych z niespełnianiem standardów idealnego piękna. Marka potraktowała różnorodność szerzej niż tylko w kategoriach estetycznych. Bohaterki są tam przedstawione jako ludzie, którzy mają swoje lęki, pragnienia i ambicje, w których realizacji przeszkadzają im szkodliwe przekonania zagnieżdżone w masowej świadomości. Wygląd nie jest tu aż tak ważny. Liczą się pewność siebie, siła (wewnętrzna i fizyczna), aktywność i osiąganie zamierzonych celów. W filmach widać bohaterki (małe dziewczynki jak w Always lub dorosłe kobiety jak w Skodzie ${ }^{14}$ czy Nike $^{15}$ ), które pokazują, że za nic mają stawiane im ogra-

${ }^{14} \mathrm{http}: / /$ www.wirtualnemedia.pl/artykul/kobiety-prowadza-stereotypy-wysiadaja-malgorzatasocha-w-kampanii-kody-wideo (dostęp: 3.01.2017).

${ }^{15}$ https://nowymarketing.pl/a/10162,reklama-dnia-atletyczne-rozbiegane-hinduski-w-nowejswietnej-reklamie-nike (dostęp: 3.01.2017). 
niczenia. Ich droga do realizacji marzeń jest żmudna i trudna, ale nie poddają się i dzięki temu są stawiane jako wzór pewności siebie i samozaparcia. Znów mamy kobiety z wyglądu różnorodne pod względem: wieku, typu urody, stylu ubierania się, $\mathrm{z}$ makijażem i bez. W przeciwieństwie do poprzedniego typu przekazu tutaj odbiorca poznaje przeszłość bohaterek i doświadczenia, które je ukształtowały. Ich wygląd nie jest istotny — ważne, że chcą osiągnąć coś, co nie mieści się w standardowym modelu kobiecości i robią wszystko, by im się to udało. Marka (tu: Always) dostrzega funkcjonujące ograniczenia i postanawia zachęcić odbiorców komunikatu do wspólnego działania, by je pokonać. Nie ma tu miejsca na ciepło i delikatność - kobiety są waleczną grupą, która musi trzymać się razem, ponieważ tylko wtedy będzie w stanie stać się motorem zmian. Więcej tu dydaktyzmu za pomocą pozytywnych wzorców. Zachęca się kobiety, by wspólnie pokonywały stereotypy, działając jak bohaterki spotów, czyli realizując własne ambicje, nie zważając na opinię otoczenia. Marka nie jest tu zawsze akceptującymi ramionami matki. Jest raczej świetnym trenerem czy mentorem. Stanowi źródło pewności siebie, daje siłę i motywuje do podejmowania aktywności. Gdy jest się z nią, nie istnieją żadne ograniczenia, a żaden cel nie jest zbyt trudny czy niemożliwy. To idealne pole do działania marek sportowych (jak Nike), samochodowych (jak Skoda) czy właśnie marek środków higienicznych dla kobiet (jak Always). To zwłaszcza tam aktywność, pewność siebie, spryt i pozytywna energia są najważniejszymi wartościami.

$$
* * *
$$

Analiza przedstawionych komunikatów marketingowych pokazała, że mimo wciąż aktualnych obserwacji poczynionych przez innych badaczy na temat komunikacji skierowanej do kobiet należałoby dodać do nich femvertising jako nowy typ przekazu. Jest to trend, którego potencjał już dostrzegło wiele marek. Tym, co wyróżnia femvertising wśród innych rodzajów komunikacji skierowanej do kobiet, jest próba oderwania się od funkcjonujących w społeczeństwie stereotypów na ich temat. Wreszcie jeśli chodzi o kobiety, część marek przestała próbować wykreować nowe pragnienia poprzez pogłębianie kompleksów i tworzenie nierealnych standardów. Zamiast tego postarano się zrealizować potrzeby już istniejące, które były przez kobiety jasno i głośno komunikowane m.in. w wynikach badań.

Nawet $\mathrm{w}$ femvertisingu można wyróżnić dwa podtypy, z czego jeden skupia się bardziej na kwestionowaniu funkcjonujących ideałów piękna, a drugi stara się pokonywać ograniczające kobiety stereotypy. Ta dychotomia stanowi podstawowy problem tego typu komunikacji. Musi ona odpowiedzieć sobie na pytanie, co tak naprawdę się liczy i na czym należy się skupiać. Można podejrzewać, że rozwój będzie następował w obu wymienionych kierunkach, bez straty dla żadnego z nich. Femvertising 
w różny sposób stara się bowiem podważać zastaną sytuację. Należałoby uznać, że jest to zgodne $z$ obecnymi trendami panującymi w myśli feministycznej. Ten nowy typ komunikacji skierowanej do kobiet jest niejako przedłużeniem trzeciej fali feminizmu i próbą przełożenia jej na zmiany w sferze komunikacyjnej, której marketing jest częścią. Rodzi to nowe wyzwania związane $\mathrm{z}$ ambicjami femvertisingu do zmiany obowiązującego dyskursu, a także ciekawe perspektywy na przyszłość. Jeszcze nigdy dotąd komunikacja skierowana do kobiet nie była tak różnorodna i żywa.

\section{Girl power! Femvertising as a new trend in marketing communications. Analysis based on selected campaigns}

\section{Summary}

Brands are a litmus paper of cultural and social changes that happen all around us. Not only must they follow the trends, they have to create them and adapt their personality and identity accordingly. One of vital questions are growing ambitions of women - and with them a frustration that has arisen from facing a reality full of limiting stereotypes. Third-wave feminism grows stronger and marketing, inherent in the social reality, forecasts new tendencies and proposes a new type of message. That's how the femvertising was born - marketing communication aimed at women, which presents them as separate from stereotyped social roles. It focuses on real problems women face when trying to pursue self-development. The article presents the results of semiotic analysis of marketing messages of brands: Dove and Always, based on a model which allows to analyze the message on the several interconnected levels of meaning. The purpose of this text is to verify what image of the world and the feminity results from the femvertising type of communication, and what challenges the femvertising faces as a fairly new type of communication. 